JSACE 1/28

An Analysis of the Plan and Facade Typologies of Boyabat's Traditional Turkish Houses

Received 2020/11/06

Accepted after revision $2021 / 03 / 25$

\section{An Analysis of the Plan and Facade Typologies of Boyabat's Traditional Turkish Houses}

\section{Zeyneb Ayla Kirenci Eruzun*}

Department of Architecture, Faculty of Architecture and Design, Samsun University, Samsun/Turkey

\section{Suphi Saatçi}

Department of Architecture, Faculty of Architecture and Design, Fatih Sultan Mehmet Vakıf University, İstanbul/Turkey

*Corresponding author: zeynebayla@gmail.com

$\Gamma$ Crossef $h$ ttp://dx.doi.org/10.5755/j01.sace.28.1.27947

This study examines the traditional housing culture of a town in northern Turkey. We aimed to determine the characteristics of traditional Boyabat houses. The Çay District, which was chosen as a case study, is the core of the housing pattern of Boyabat. This study analyzed the features, plan and facade types of these houses in order to produce a table of their plan and facade typology. Documenting the vernacular architecture of Boyabat will assist the conservation of the settlement's traditional texture. This data can also serve as a guide for the local municipality's site management projects and be passed on to future generations.

Keywords: vernacular architecture, Turkish houses, typology, Boyabat, architectural heritage

\section{Introduction}

Sinop is a province located in Turkey's Black Sea region (Fig. 1). Sinop is the Black Sea's most important natural port, and the province was once home to a number of ancient civilizations, including Kaskians, Hittites, Phrygians and Cimmerians (Eser, 2006). Famous as the birthplace of Diogenes, Sinop was used as a trading base between Mesopotamia, the Anatolian hinterlands and the Black Sea region. The people of Miletus strengthened their navy using the high-quality pine timber they obtained from the forests in the vicinity and from cities such as Trapezus (Trabzon, 757 BCE), Kerasus (Giresun) and Kotyora on the Black Sea coast. Sinop was the district center under the Sanjak of Kastamonu during the Ottoman Empire, before becoming the sanjak center of Kastamonu Province in the Tanzimat period (a period of Ottoman reform that lasted from 1839 to 1876). In the Turkish Republican period, it was made a province (Öz, 2020).

Boyabat, the subject of this study, is the largest of Sinop's districts. The most distinctive feature of the district, which is rich in terms of historical and cultural artefacts, is its traditional houses. The purpose of this study is to document the buildings that have value as cultural heritage, and traditional and local architectural features that are in danger of disappearing. It also aimed to analyze their plans and facade typologies, to revive traditional artisanry in the future with this knowledge base, and thereby, to contribute to the cultural heritage of the region.
Journal of Sustainable Architecture and Civil Engineering Vol. 1 / No. 28 / 2021 pp. $40-55$ DOI 10.5755/j01.sace.28.1.27947 


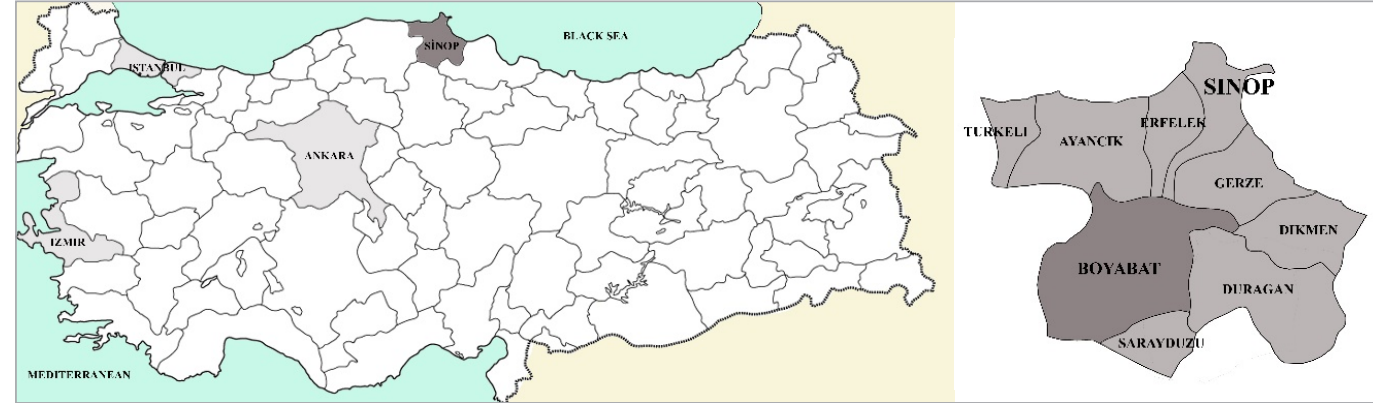

Boyabat's history dates back to the Late Chalcolithic Age (4500 BCE). In 2000, excavations carried out in Kovuklukaya Höyük, 15 kilometers from Boyabat, discovered a bronze casting master's house from the early Bronze Age, along with materials belonging to the Late Chalcolithic Age (Tosun, 2013).

Boyabat passed into the hands of the Danismentli, followed by the Seljuks, and the Kingdom of Pontus. Later, it fell back under the rule of the Seljuks. In 1262, it was absorbed into the Pervane Beylik, and it then passed through the Jandarids and Isfendiyarids before Sultan Mehmed the Conqueror added it to his Ottoman territory in 1461 (Eser, 2006).

Boyabat was an administrative division of the Sanjak of Kastamonu until the Tanzimat period. With the declaration of the Tanzimat, Kastamonu Province became a sub-district of the Sanjak of Sinop, and since 1868, it has been a district of Sinop (Başoğlu, 1972).

Boyabat, which has hosted different civilizations throughout its history, has a rich architectural heritage. It is densely populated, and its houses have unique characteristics, shaped by the lifestyles and needs of the local people, environmental conditions and the use of local materials. Boyabat's many unique architectural examples of the characteristics of traditional Turkish houses led to its selection as the study area.

The Black Sea region is the rainiest region in Turkey. Wood was used as a building material because it is heavily forested, and sufficient resources are available. Wooden materials are durable and highly resistant to moisture and heat. Stone is another material used in local architecture. Wood is the main building material in many regions of Anatolia. The use of wood is affected by climate, material stocks, requirements, social and cultural conditions and economics.

The traditional homes of the Black Sea Region are a rich cultural heritage of historically diverse ethnicities. Their plans and architectural forms reflect regional history, cultures, material use and most importantly, the local climate and topography, and the skills of the local masters. Their construction techniques, layouts and facades are all unique. Their plans and facade
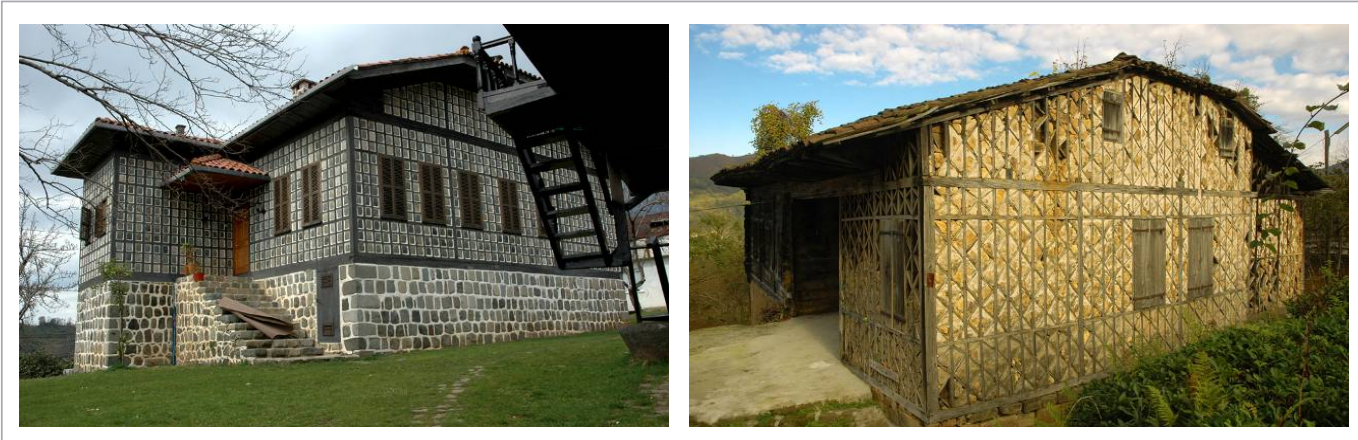

Fig. 1

Location of Sinop and Boyabat

Fig. 2

Vernacular Houses, Eastern Black Sea Region (Özen et al., 2012) 
Fig. 3

Rize (Başkan, S., 2008)

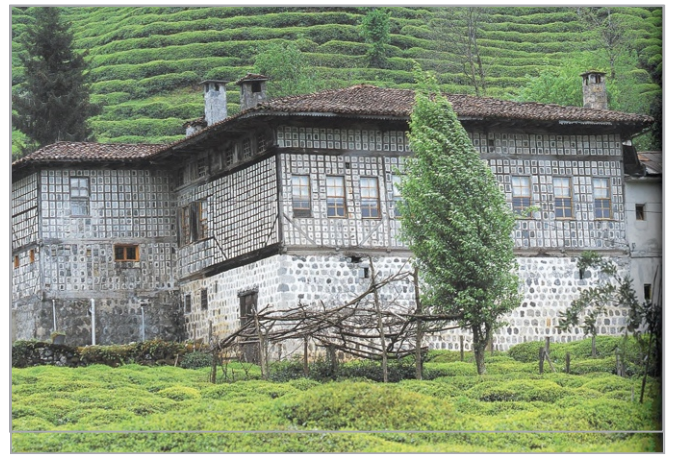

Fig. 4

Kastamonu

(Saatçi et al., 2018)

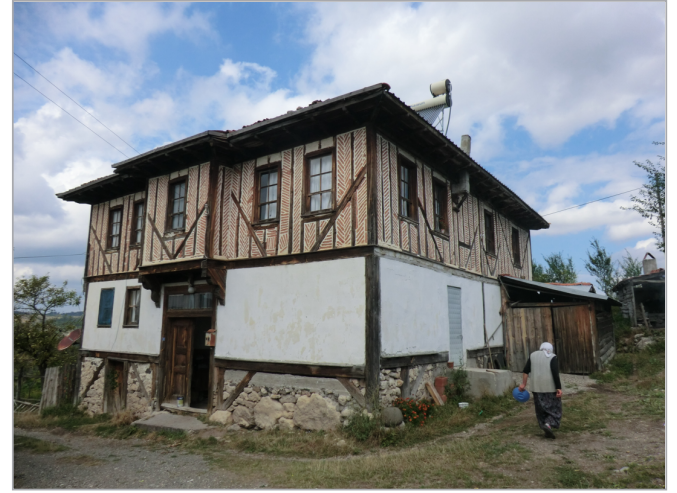

aesthetics elegantly combine topography and lifestyle needs.

Wood is the only building material that can regenerate itself and clean the air (Bostancıoğlu et al., 2004). It can be used for building elements such as walls, floors, roofs, doors and windows. Stone is used for the ground or basement floors to reduce the potential harm of ground moisture in contact with the building and prevent water from reaching the wooden parts of the house. It also provides an organic transition to wood material (Özen et al., 2012). Traditional Black Sea houses are mixed-system structures with stone masonry ground floors and the wood-framed upper floors. In the architecture of the Black Sea region, the ground floor generally functions such as a barn for storage, and the livestock also heat the houses in the winter (Fig. 2, 3, 4). The second and third (if any) floors of the houses are their living spaces.
Materials and Method

\section{Analysis of the Urban Environment}

In this study, fieldwork was conducted using qualitative data collection methods such as observation, interview and document analysis. It was done in three stages: literature review, data collection and data analysis. The literature review researched the characteristics of traditional Turkish houses, traditional architecture and materials, examples of traditional houses, and the history and houses of Boyabat. The data collection phase included obtaining maps from the municipality where the registered buildings are marked, examining the neighborhoods with traditional houses by doing fieldwork, selecting the neighborhood and houses to be studied, taking photographs and surveying. In the Çay Mahallesi, the study area, seven houses were evaluated, and their similarities and differences with Boyabat's houses were specified.

Here are this study's objectives:

1. To examine the architectural features of traditional Turkish houses and the factors that affect them, including history, climate, topography, and social and cultural features.

2. To examine the similarities and differences between the houses in Çay Mahallesi and the traditional houses in Boyabat, and to specify their typologies.

3. To demonstrate the importance of traditional houses in the context of cultural heritage.

Of the buildings that stand out for their historical and architectural features in this district, which boasts archaeological, natural and urban sites, the most important and well-known is undoubtedly Boyabat Castle (Fig. 5). The castle is surrounded by walls and has an observation tower located on a hill that overlooks Boyabat.

Both Boyabat Castle and the Kolaz River have played an important role in the formation and development of the district and its urban landscape. The fertile lands along the Kolaz River are very suitable for agriculture (Fig. 6). The settlement grew beneath the castle and expanded outwards. 
According to the travel writings of Ainsworth (1807-1896), the adobe houses of Boyabat extended to the valley where Kaz Creek is located. There were fruit trees and fields nearby. About 30 houses in the castle dated from the feudal lordship of Hüseyin, who is said to have been one of the last sipahis (Esemenli, 1990). Ainsworth also mentions the existence of wooden houses that made up the town's architecture at that time.

Boyabat is a town with protected areas and a mixture of natural, urban and archaeological sites. The area where Boyabat Castle is located is limited to the archaeological site, the hill on which it sits, and the Kolaz Stream and its periphery, which are naturally protected areas (Tosun, 2013). Within the boundaries of this site, 176 private buildings and 11 monumental buildings were registered from 1989 until 2011 (Fig. 7).

The district's historical sites include: Kırkkızlar Rock, the White Masjid, the Grand Mosque,
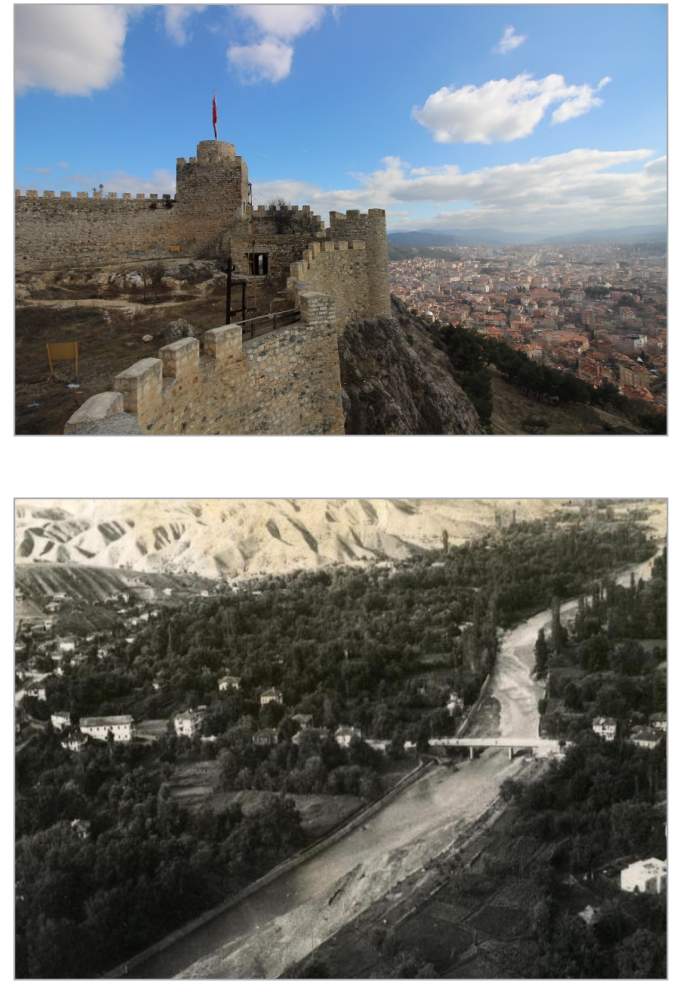

Fig. 6

Kolaz (Gazidere) Stream (Photograph by Resul Boyabat)

Fig. 7

Map of Boyabat's Historical Sites and Registered Buildings 


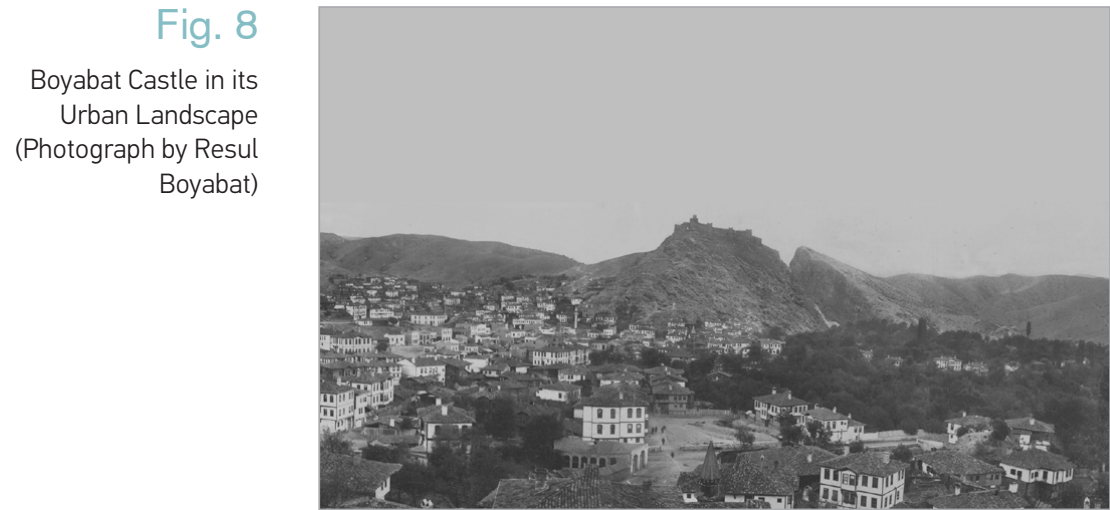

Fig. 8

yabat Castle in its Urban Landscape (Doyat)
Kandilsiz Masjid, Şeyh Mosque, Gökdere Mosque, Kaya Mosque, a madrasa, a tomb, the Salar Village Rock Tomb, the Basalt Rocks, İnönü Primary School, a girls' vocational high school, the Military Office (Old Hospital), the Büyük Kemer Bridge and the Paşalığlu Village Church Ruins. The Şeyh Mosque Fountain, the fountain on Keçeli Street and the Kirazlıdere Aqueduct are among its waterworks.

The landscape is a primary determinant of the locations of traditional houses. In Boyabat, a town built on hills and slopes, the dominant feature in the landscape is the castle. The residences on sloping land are all designed to face the castle, while their other facade faces the garden or street. The facades of the residences on flat land are designed to look onto their gardens of the street. The original look of the town can be seen in old photographs (Fig. 8).

\section{The Results of the Analysis of Traditional Boyabat Houses in the Çay Neighborhood}

The traditional construction system is usually timber frame. There are also examples where wooden posts were filled with mudbrick, brick or rubble stone, or left unfilled and covered with laths (Seçkin et al., 2002). Boyabat's original settlements are garden houses with two entrances: a main entrance and the garden entrance.

The traditional houses in the Çay Neighborhood were built according to a set of criteria: suitability for regional conditions, effective use of materials, flexibility, adaptability to new lifestyles and cultural diversity, neutrality, simplicity and realism. These criteria, created by the analysis of traditional construction methods, are among the sub-components of sustainable construction (Karaman et al., 2015). The Çay Neighborhood traditional houses examined in this study meet all or some of these criteria and have preserved their authenticity. It was selected as a case study due to its unique architectural features (Fig. 9).

Located to the west of Kemaldede Mosque and known by this name by the town's older generation, Ekiz Street (Fig. 10), Kandilci Street, Kayaarası Street, Şeker Street, and Çay Street are its most historic
Fig. 9

The Location of Çay Neighborhood in Boyabat's Protected Areas

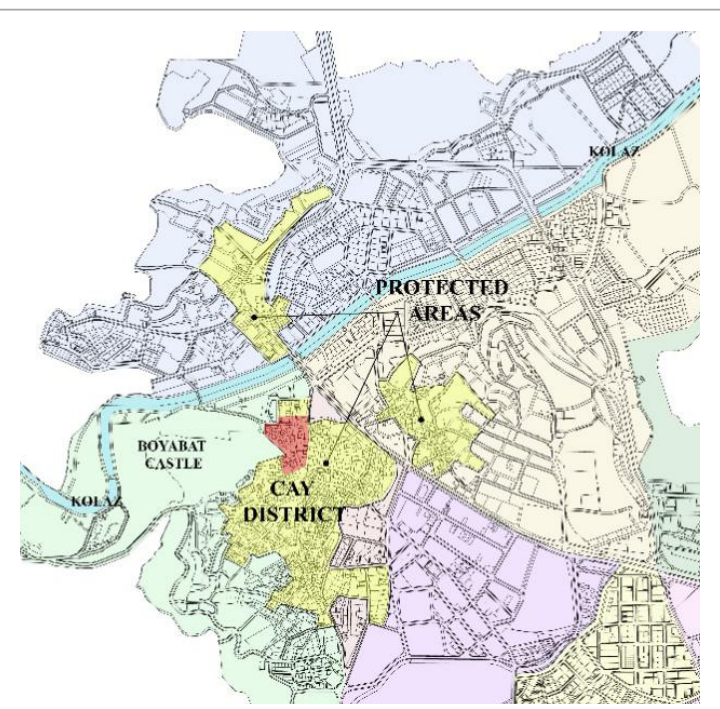




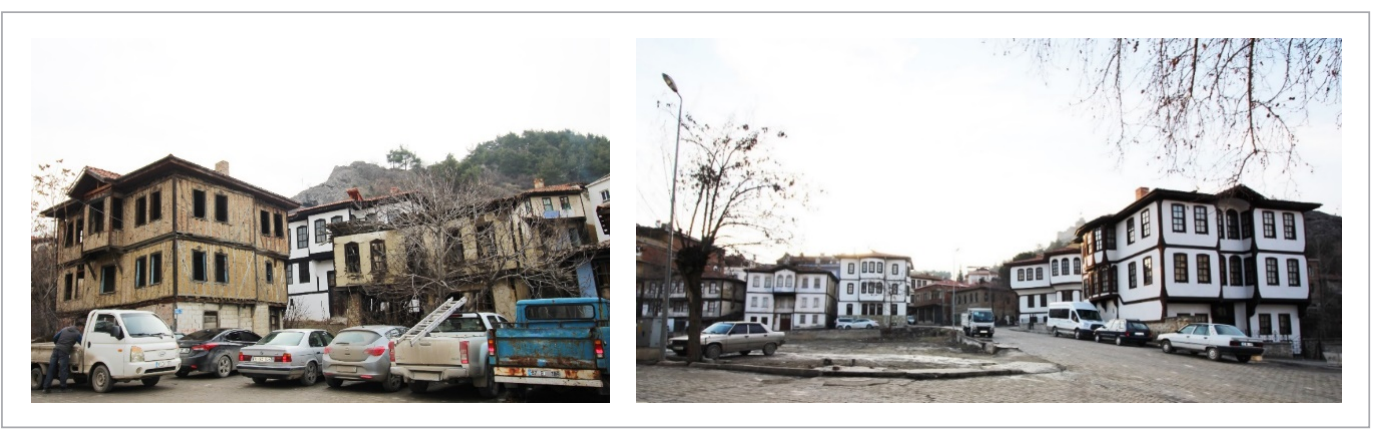

Fig. 10

Ekiz Street (left) and Zübeyde Hanım Street (right) (Kirenci Eruzun, 2017)

streets. The Çay Neighborhood is exemplified by Bayram Street and Zübeyde Hanım Street, which have the town's original look and where its traditional houses are located. This section examines the layout, construction systems, building elements, plans and facades of seven buildings in the Çay Neighborhood.

\section{The Nurten Yayla House}

a. Site plan: The building, located on a plot that opens onto Ekiz Street on three sides, consists of a ground floor and two upper floors. It has three entrances, two north-facing and one south-facing. Since the slope of the land increases to the west, some of its northern and southern facades are underground. Its entire eastern facade faces Ekiz Street and is visible from the street level (Fig. 11).

b. Layout: Built according to a rectangular plan, there are two entrances on the north side of the building and one entrance on its south side. The west entrance of the northern facade opens to a single room. The stairs to the upper floors are accessed through a door in its interior. Two windows open to the street from the rectangular sofa (main hall) from which the other rooms on
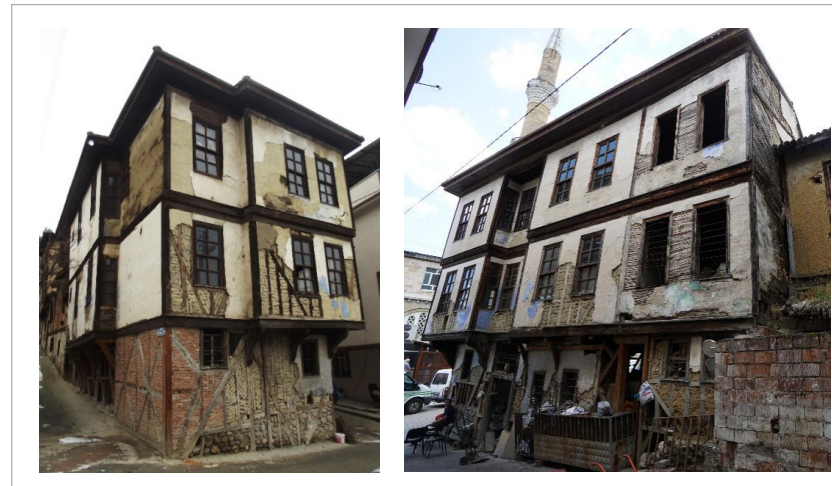
this floor are reached.

c. Construction system: The building is constructed of stone masonry up to the sub-basement level. The upper floors are a timber frame structure.

d. Building elements: The building has three entrances. One leaf of the double-leaf, triple-partitioned wooden door is broken. It has a top window. There is also a single-leaf wooden door on the same facade. The windows of the building are wooden sash windows.

e. Features of the facade: The original facade of the building is covered in plasterwork. The ground floor of the timber frame building is filled with brick, stone and mudbrick. The upper floors are filled with mudbrick. The windows are wooden sash windows. The doors are no longer intact and appear to have been filled in with scrap wood. The structure ends with a wide canopy, and its eaves are covered with wood. Its roof is tiled in the Turkish style.

\section{The Şefik Özerkan House}

a. Site plan: Located on the corner of Ekiz Street and Kaya Street, this building has a ground floor and two upper floors. It is built on slightly sloping terrain. Adjacent to its western wall, there is a rectangular, single-story brick annex. There is a garden entrance on its north side.

b. Layout: The northern entrance leads to the sofa. There is a room to the east of the entrance and a kitchen to the west.
Fig. 11

The Nurten Yayla House (Kirenci Eruzun, 2015) 
Fig. 12

The Şefik Özerkan House (Kirenci Eruzun, 2017)
Fig. 13

The Osman Cistık House (Kirenci Eruzun, 2017)

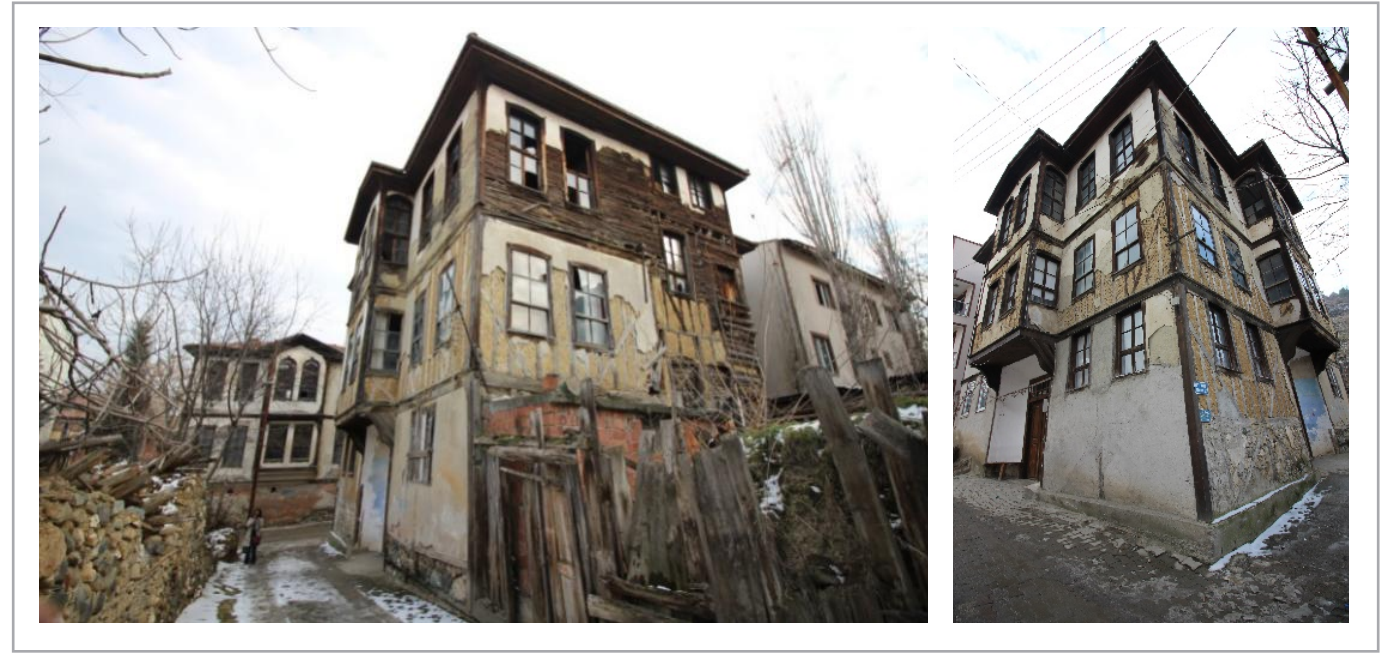

c. Construction system: It is made up of stone masonry up to a height of about 1.5 meters, while the upper floors have a karkas (timber framework) system. It is supported by wooden buttresses between wooden posts. The area between the karkas section of the ground floor and the wooden elements of the first floor is filled with mudbricks.

d. Building elements: Its two doors are wooden and double-partitioned. It has wooden latticed windows. There are bay windows above both entrances (Fig. 12). The bay windows are located in the middle axis of the facade, just like the entrances, and are on the second and third floors. The bay windows are supported by two wooden elibögründe (cantilevered support brackets). The northern, southern and eastern facades feature wooden decorations on the pediment of the third floor.

e. Features of the facade: The facade is covered in plasterwork. However, most of it has fallen off, and the load-bearing system is clearly visible.

\section{The Osman Cistık House}

a. Site plan: This building on Kayaarası Street has an elevated ground floor and two upper floors. It is built on a west-east orientation.

b. Layout: The entrance of the building opens onto a taşlık (stone courtyard). Directly opposite the stairs on the second floor is the sofa. On this floor, the room facing the northern facade, next to the stairs, also has an entrance. On the third floor, the sofa is opposite the stairs, and other rooms branch off from it. The sofa section has a south-facing bay window.

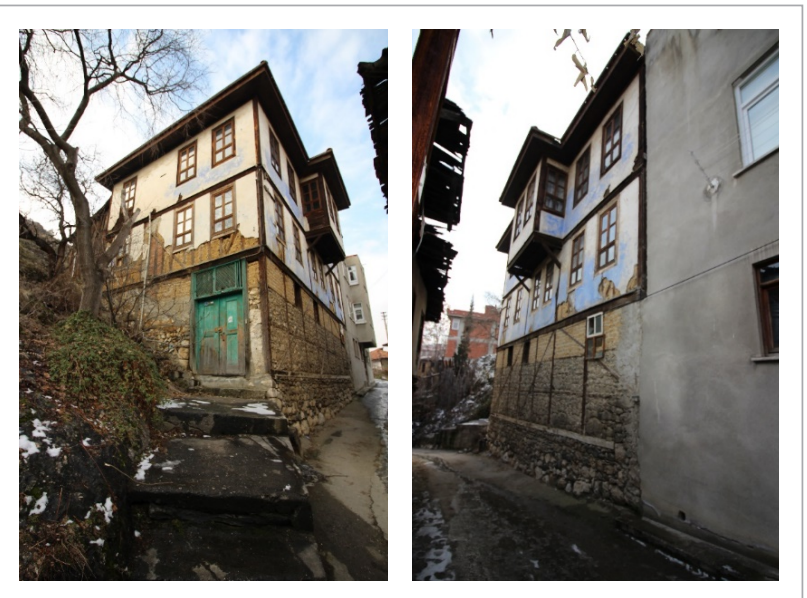

c. Construction system: Up to the basement level it is constructed of stacked rock. The upper floors are constructed around a karkas. While wooden pillars and stone are placed between the buttresses on the ground floor, it is filled with mudbrick on the second floor.

d. Building elements: Its entrance is a wooden, double-partitioned and double-plated door.

e. Features of the facade: The house's upper floors are covered in plasterwork. The ground floor is exposed 
masonry, and the load-bearing system is visible. Brick was used as a filler between three wooden pillars in a small section of the western facade. In the plasterwork on the facade of the first floor, mudbrick was used as a filler in the karkas system. Parts of the second floor plasterwork have fallen off (Fig. 13).

\section{The Süleyman Baş House}

a. Site plan: This building on Kayaarası Street has a ground floor and two upper floors. Its entrance faces north. The house is surrounded by a wall and is higher than other nearby houses (Fig. 14).

b. Layout: A rectangular section of the ground floor is underground and not in use. The stairway opens to the sofa and from here other rooms branch off. The second floor has three rooms: a kitchen, a bathroom and a washroom. The middle axis of the northern facade has a bay window on the third floor. A staircase leads to the sofa.

c. Construction system: Up to the basement level it is constructed of stacked rock. The upper floors have a karkas.

d. Building elements: Its entrance is wooden, double-partitioned and double-plated door. Adjacent to it, there is another single-leaf wooden door with three plates and a window. The windows are wooden sash windows.

e. Features of the facade: In the middle axis of the northern facade, which has the entrance, there is a bay window on the third floor. The bottom of the bay window is overlaid in wood and is supported by two wooden brackets. The structure ends with a wide canopy, and the eaves are overlaid in wood. It has a hipped roof covered with Turkish-style tiles.

\section{The Cemal Yanıkel House}

a. Site plan: This building on Çay Street has a ground floor and two upper floors.

b. Layout: The building has a square plan with a main north-facing entrance and another south-facing entrance. The stairs adjacent to the ground floor's western facade led to the sofa, which branches of to three rooms and lavatory areas. The floor plan rises slightly from the central axis of the northern facade and includes a balcony. On the third floor, a landing can be reached by ladder for access to more rooms.

c. Construction system: The building has a karkas construction system. The wooden pillars and buttresses on the ground floor and second floor are filled with mudbrick. The third-floor features laths. d. Building elements: The main entrance on its northern facade is a wooden, triple-partitioned and double-leaf door. The balcony on the second-floor plan is located just above the entrance. The entrance to the ground floor of the southern facade is also a wooden, triple-partitioned, and double-leaf door. The staircase adjacent to the facade is wooden. The bay window on the third floor of the southern facade is supported by two wooden brackets and extends over the entrance on the ground floor. The bay window on the southern facade has round-arched wooden sash windows. On the northern and southern facades, two windows on the upper floors have been modernized at some point and combined (Fig. 15).
Fig. 14

The Süleyman Baş House (Kirenci Eruzun, 2017) 
Fig. 15

The Cemal Yanıkel House (Kirenci Eruzun, 2017)

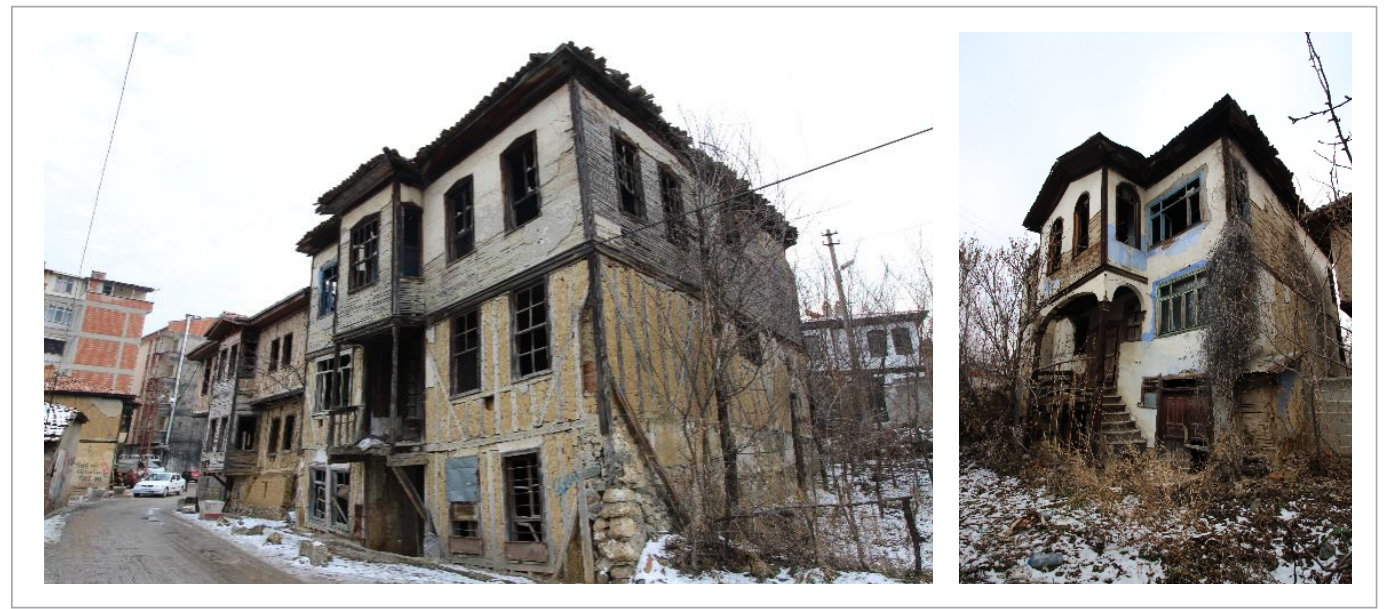

e. Features of the facade: Wooden floor moldings run around all the facades and join with wooden corner finishing slats at the corners of the building. The bay window is covered with a wooden lattice. Unlike other wooden houses, there are wooden posts instead of brackets under the bay windows. The structure ends with a wide canopy. The eaves are covered with wood. It has a hipped roof and is covered with Turkish-style tiles. The roof is in bad shape.

\section{The İsmail Eski House}

a. Site plan: Located on a dirt road off Ekiz Street, this building's interior is still intact. It consists of a ground floor and two upper floors. Its entrance faces east.

b. Layout: Its plan is almost square. There is no interior entrance to the woodshed north of the entrance. The entrance of the warehouse located on the southern side is at the end of the stairs. The stairway opens to the sofa and from this section, three rooms, a bathroom and washroom can be accessed. The upper two floors' plans are almost identical. However, unlike the second floor, in the third-floor plan has a bay window on its east facade.

c. Construction system: The ground floor is stone masonry, and the upper floors have a karkas.

d. Building elements: Its entrance is a wooden, triple-partitioned and double-leaf door. It has a top window. The windows are wooden sash windows.

e. Features of the facade: In the middle axis of the eastern facade, which has the entrance, there is a bay window on the third floor (Fig. 16). The bottom of the bay window is covered in wood and supported by two wooden brackets. The structure ends with a wide canopy and the eaves are overlaid in wood. It has a hipped roof and is covered with Turkish-style tiles.

\section{Fig. 16}

The İsmail Eski House (Kirenci Eruzun, 2017)

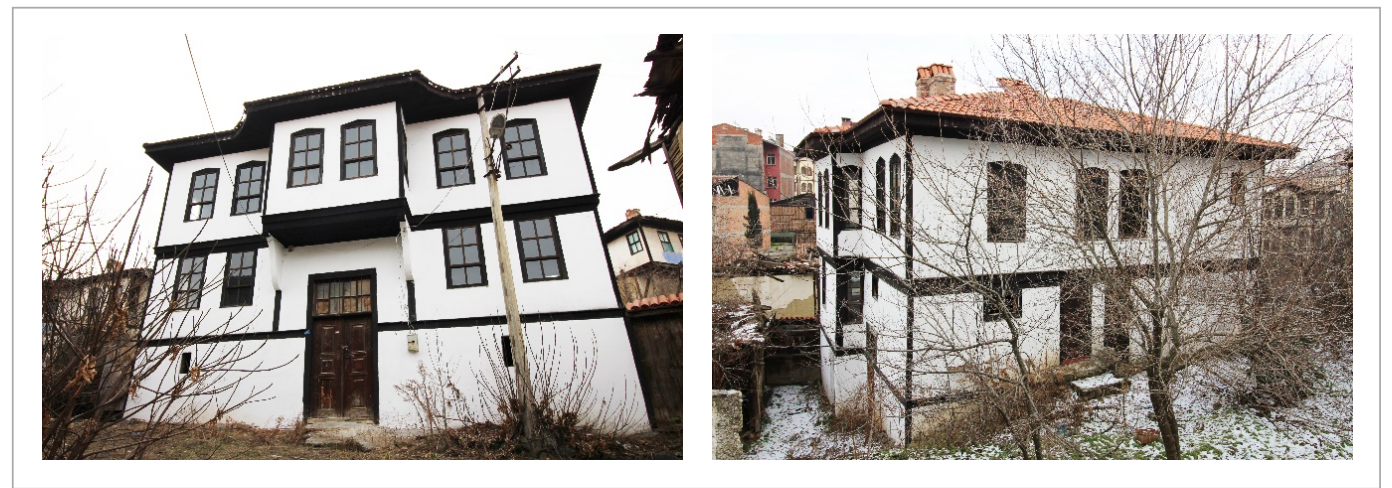




\section{The Adil Kahramanoğlu House}

a. Site plan: This building on Çay Street has a basement, a ground floor and a second floor. Its entrance faces south.

b. Layout: It has a rectangular plan. Its entrance opens onto a taşlık. There are rooms on both sides of the taşlık. There is an exit to the garden from the room on the east side. The sofa is reached by four steps leading up from the taşlık. The kitchen is on the east of the sofa, and the staircase and washroom are to its west. Stairs lead up from there to three other rooms and bathrooms.

c. Construction system: The basement is stone masonry, and the upper floors have a karkas, which is supported by wooden buttresses between wooden posts. Adobe was used as a filler in the karkas system.

d. Building elements: Since the entrance of the building is blocked with wood, it cannot be seen in its entirety. It has a top window. It appears to be a wooden, double-partitioned and double-leaf door. The central axis of the southern facade's second floor has a bay window. The bay window is covered with a wooden lattice. It is supported by two wooden eliböğründe. Two windows on the west ground floor have been covered up (Fig. 17). Only the eastern window has wooden support brackets.

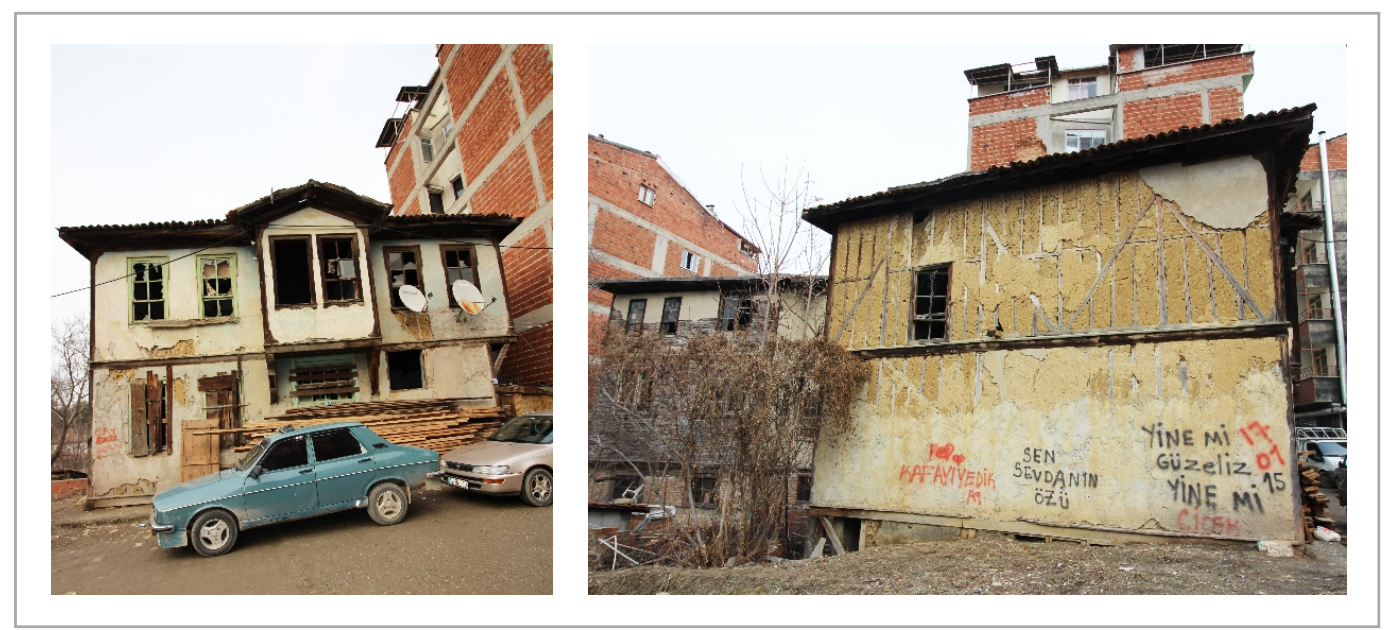

Fig. 17

The Adil Kahramanoğlu House (Kirenci Eruzun, 2017)

Features of the facade: Wooden floor moldings run around all the facades and join with wooden finishing slats on the corners of the building. Its eastern facade has one window on the second floor above the stairwell. It has a basement, ground floor and upper floor on the north side, and a ground floor and an upper floor on the south side. The structure ends with a wide canopy. Its eaves are covered with wood, and its roof is tiled in the Turkish style.

Traditional houses have a distinctive architectural character, the result of climatic and geographical features, and the social, economic and cultural life of the local people. They reflect the architectural understandings, tastes and social and economic conditions of the periods in which they were constructed. In traditional architecture, the houses are positioned in the direction of the dominant landscape not to interfere with the views and light of neighboring houses. These types of settlements are compatible with nature, and each building respects the views of those nearby.

This study examined the houses in Boyabat's Çay Neighborhood (Fig. 18). In addition to determining their typological features, differentiating features were also included. The houses are adapted to the local situation, and similar types can be grouped together. Although no two houses are ever exactly

\section{Discussion}


Fig. 18

Houses in Boyabat's Çay Neighborhood

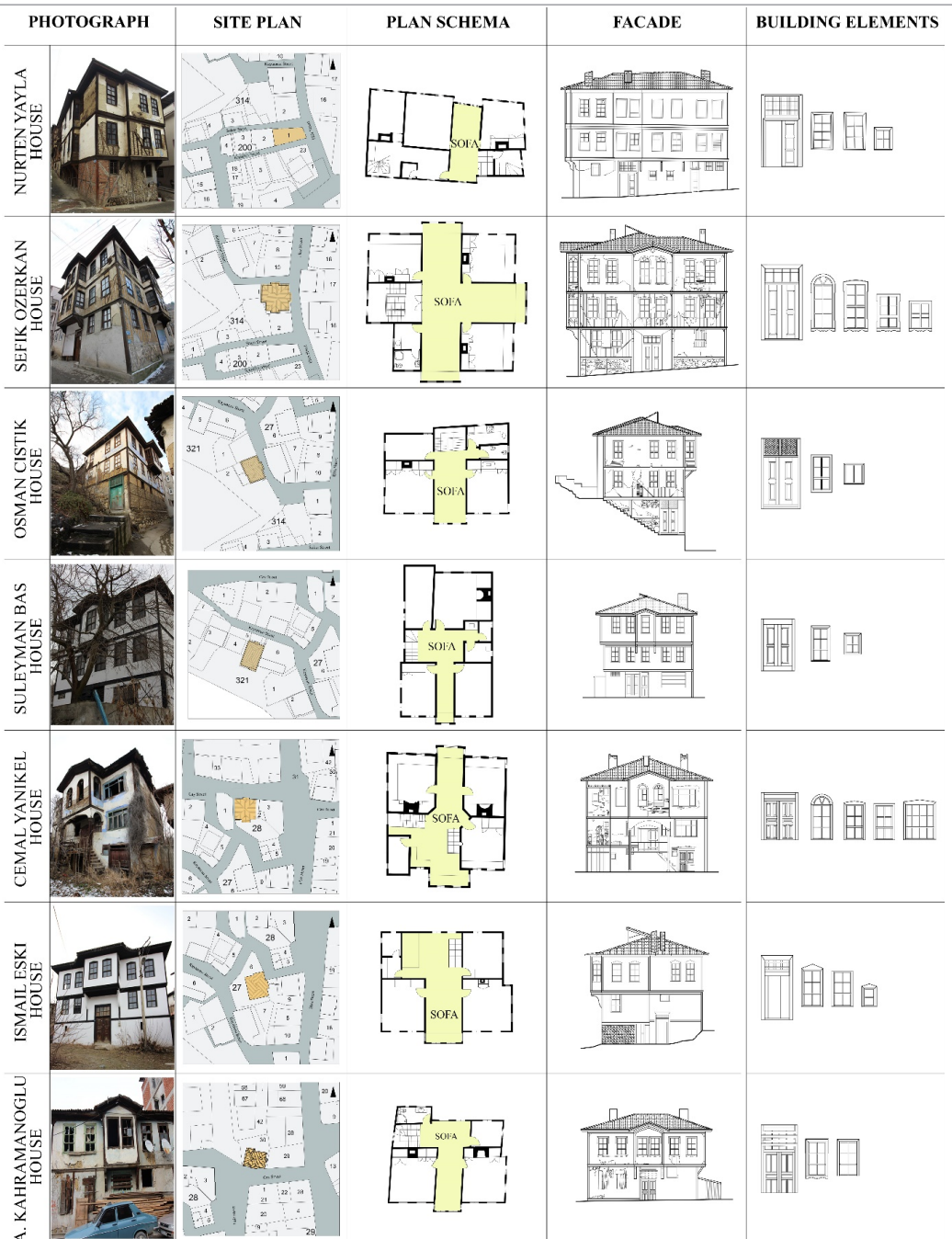

the same, those in each region have defining characteristics. This study describes the features shared by the houses' plans, facades and layout, as well as features that are rarer and unique to each house.

\section{The Layout Features of the Boyabat Houses}

Boyabat's traditional houses are oriented by the most distinctive features of the local topography and the castle, which dominates the landscape, so as not to block each other's views. The houses have two or three floors. The ground floor often functions as a taşlık, barn, cellar and woodshed, while the living areas are on the second and third floors. The ground floors usually do not have windows. Since they are in daily use, the upper floors are built with windows and differ in layout due to their relationship with the environment (Çobancaoğlu, 2003).

The ground floor is a passage area, and the upper floors are reached by staircase. The stairs lead to the sofa, and the rooms branch off from it. The plans of houses with one or two entrances are shaped around the sofa. Thus, the feature that most distinguishes the Turkish house from Western European houses is that the rooms all branch off from the sofa, and the sofa creates a square for movement inside the house (Eldem, 1954). At the same time, this square is a gathering area for the household.

The smallest units in these plans are the rooms. These rooms (perhaps most equivalent to 'chambers' in old English houses) can be grouped together by the fact that they are similar in shape, 
size, location and their relation to other units. They tend to converge on the sofa. Sedad Hakkı Eldem classified traditional Turkish houses according to the sofa into four types: those with an outer sofa, those with an inner sofa, those with a middle sofa and those without a sofa.

The sofa is the name given to the large space onto which the doors of chambers open in traditional houses (Hasol, 2010). The sofa was a common area providing a passage between rooms and had an important place in the daily life of Turkish families (Beceren Öztürk et al., 2017). Due to the space, it occupies in the plan and the important role it plays, the sofa should be considered the primary design element of traditional Turkish houses. The shape of the sofa directly determines the type of house. The sofa creates rooms in three different basic layouts, depending on whether it is in front of, behind or between the rooms (Eldem, 1954).

The Boyabat houses usually have an interior sofa. The rooms open onto the sofa. Stairs are generally positioned within the sofa, while some are in a separate section with a doorway. A definitive generalization for the shape of a sofa cannot be made since this is determined by the plan of the house.

When the stairs are located within the sofa, the plan is not much altered. However, when they are outside the sofa, this affects the plan. In houses with an outer sofa, the staircase is found in an unoccupied part of the hall and rarely in the row of rooms. However, in houses with an interior sofa, a separate place reserved for the staircase is more common (Eldem, 1954). The plans analyzed in this study with an interior sofa also had a separate place reserved for the stairs. Among the types of staircases seen are single-banister, double-banister and spiral. Some stairs are restricted to the upper floor by walls and doors. One has to pass through a door to reach the sofa. The sofa's function is as a landing that leads to other rooms, as well as a gathering place.

In Boyabat's houses, the entrances are positioned at the center of the building. Some houses have two entrances, one on the ground floor and one on the second floor. This allows the ground floor to be used for storage purposes and the living areas of the house to be separate. There are also houses with two entrances on the same floor. In them, one can enter from two different sides of the ground floor. The two different entrances are separated by staircases. These entrances can separate shared and private spaces.

In some types of houses, one end of the hall is left open and faces onto the street. Large families would close off this section between the two rooms and turn it into a small room. Although this narrowed the hall, it offered an extra room for large families. In Boyabat houses, the need for the hall to receive light was generally considered. Very few of the examples examined had completely enclosed halls. Efforts were made to enable the houses to make use of natural light.

The houses usually have two large rooms on the entrance side. All variations were provided by the displacement of the axes, differences in the size of the rooms and the arrangement of recesses and protrusions. This flexibility, which allowed for transition from a simple plan to any complex plan desired, was an important feature of this architectural form (Kuban, 1995). Sometimes a small room was created by closing off the remaining section in the middle of these rooms, or it was left open and arranged as a seating area with ottomans. These two large rooms feature symmetrical cupboards positioned on either side of the ocaklık (hearth). They are the most spacious rooms of the house and contain the most features. In a few cases, the largest room in the house also had a bathroom. Generally, every house has a section especially designed for a sink (other than those in the bathrooms). The sink is sometimes set within a niche and sometimes as a separate space connected to the bathroom. Among the original furnishings of these rooms still remaining are candle niches, yüklük (cupboards for bedding) (Fig. 19), sedir (low couches), fireplaces and sergen (display shelves) (Fig. 20).

One of the original features of the plans for these rooms is that yüklük, ocaklık and sedir were built into the walls (Tosun, 2013). 
Fig. 19

Candle niche (Küçükbaș, 2008), yüklük (Kirenci Eruzun, 2017)
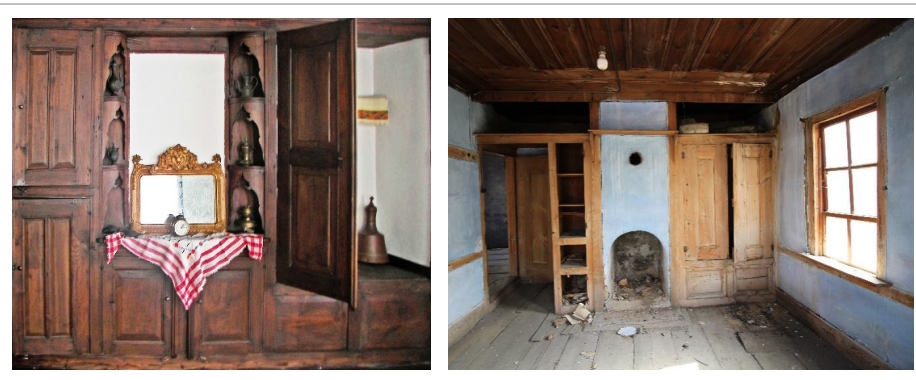
of the house is also used as a kitchen. A fire was lit to cook or heat meals in the kitchen. Like the fireplaces in other rooms, there are cupboards next to the fireplace in the kitchen. The cabinets are divided into small compartments called göz and have glass covers.

Yüklük are cupboards in which mattresses were stored during the day. They are usually located opposite the main windows by the entrance. They also had the function of providing sound insulation between the rooms. In these rooms dominated by a horizontally oriented design, fruit and small pots were placed on sergen just above the lower windows, thus reinforcing the feature of horizontality even more (Kuban, 1995).
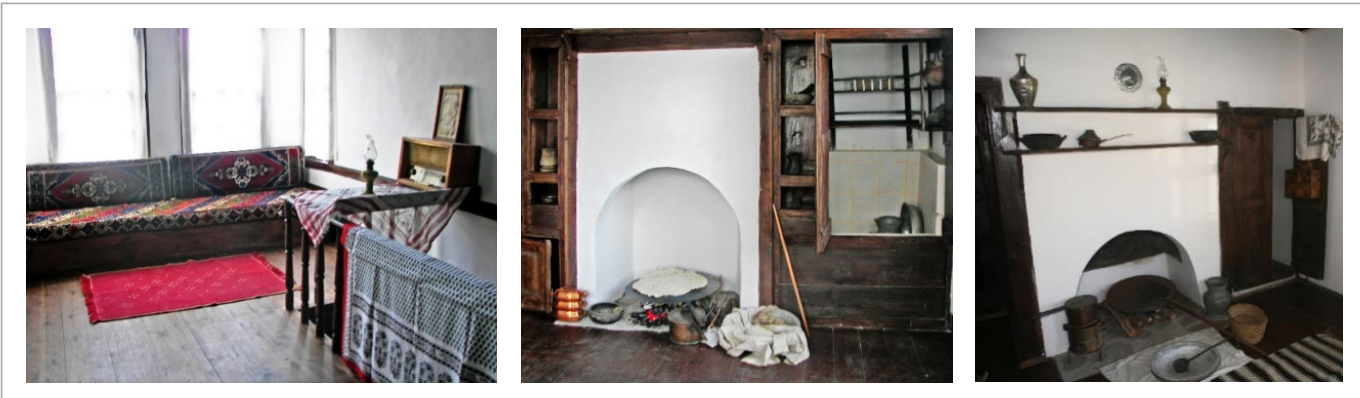

Sergen feature in some rooms. They are shelves that are flush with the ceiling. Kuban described their originality and functionality: "The sergen were the limit of accessibility, often dotted with items and fruit. They were a functional cornice" (Kuban, 2017).

\section{The Features of the Boyabat House Facades}

The elements that shape the facades of Boyabat houses are numbers of floors, protrusions, doors, windows, jambs, floor moldings, cornices, light installations and roof types.

Traditional houses usually have two or three floors. Two-story houses are more common. Three-story houses have a more specialized window and facade setup and look like mansions.

Up until the eighteenth century, the exterior surfaces varied little, and the layout was more compact. However, after that date, with increased need for light, bay windows became more common, and the facades were actively used (Çobancaoğlu, 2003). In traditional houses, cumba (bay windows) are important elements that contribute to their character. The facades that face the street generally protrude outwards. There are also houses with two, three or four facades. The cumba are usually in the center of the houses' facades and are supported by cantilevered wooden brackets. Some of them are plain, and others are decorated with wooden carvings. The plinth wall can be seen from the outside as a stone filling. The upper floors are covered with lath and plaster. It is possible to see the load-bearing systems and materials of the houses whose plasterwork has 
fallen off over time. The ground floor of the houses was built in stone masonry, and the wooden karkas of their upper floors were filled with mudbrick. The ground floor was made stronger by this stacking method. At the same time, problems with ground moisture were solved by raising the sub-basement level. The mudbrick filler material is rectangular and can be placed straight or diagonally. Since the materials used in these houses are similar, and they are similar in size, their facades resemble one another. This creates an integral look for the houses of Boyabat and means that they are the same type of house.

Few decorative elements are used on the facades. Some houses have light decoration on the roof joints and on the tops of their cantilever brackets. Wooden moldings that show the alignment of the floors are common features. There are profiled wooden decorative elements on the corners of the facades, and, when they are used, they are located on each floor. Profiled wooden cornices between the roof and the top floor are also a characteristic feature of traditional houses.

The types of windows can be grouped into rectangular, arched and trellised. The most common type is the rectangular window. In some examples, rectangular windows are detailed with triangular pediments or curved wooden ornaments. Partitioned wooden sash windows change the look of the house depending on the number of panes used. It can be seen that this number is usually the same horizontally but varies vertically. Many houses have windows that are arranged in three rows of six panes. There are also examples with two rows of four panes, or four rows of eight panes. Four-pane windows are generally used on the ground floor. If any layout dominates, the houses can be said to use the 2-2-2 window layout most commonly. Those with 2-1-2, 2-3-2 or 2-4-2 layouts are few and far between.

Arched windows are used only for bay windows. Generally, all the windows of these houses are rectangular, except for semicircular arches of the bay windows. This makes the bay windows more pronounced. Some types of windows also have decoration on the windowsills. The number of windowpanes also varies according to the size of the window. Other than bay windows, the houses have double-leaf, rectangular, wooden sash windows.

Lattice windows are used on the ground floors to provide privacy. The lattices are functional elements, usually used in rectangular windows with slats placed diagonally. The latticework commonly used in traditional houses covers only half of the entire window and can be lifted up when desired. In the nineteenth century, latticed windows were a characteristic feature of Boyabat's streets (Kuban, 2017).

Another feature of the windows is their opening system. Since the sedir are positioned just below the windows, the most logical style of window to avoid disturbing the people seated on them was vertical sliding windows (Kuban, 1995).

While the entrances of houses can be built into a single facade, there are also houses with entrances on two sides. The entrances in the center of houses are positioned beneath the bay window of the houses that have them. They are aligned at the midpoints of both the house and the bay window.

The entrances are wooden, double or triple-partitioned, double-leaf doors. Windows are another feature. If the entrance opens to the taşlık, the windows also illuminate this section. Entrance doors are emphasized in some houses with columns and capitals. Some have, triangular pediments and ornaments, like the windows.

Traditional houses feature hipped roofs covered in Turkish-style roof tiles. Chimneys are square or rectangular, and irregular examples are very rare. Some roofs have a section called a cat house (kedilik), which provides an exit to the roof and is an animal-friendly element that is specific to the region. 
This study, which aimed to create an archive of the houses that make up the traditional landscape of Boyabat and are in danger of being lost, was intended to evaluate documents that will form a knowledge base for these houses, to gather data for buildings that are to be restored in the future, to help revitalize the region, and to thereby contribute to the region's culture. In line with this study's aim, the traditional houses of Boyabat were listed, and their features were described, the layout of the historic streets was examined, original plans and facade types were documented, and inventories were prepared.

The common features of the Boyabat houses mean that they have a unique character and form a group of their own. Here is a summary of the houses' layout, plan and facade features:

- The houses never block each other's views and are in harmony with the local topography.

- The houses are fully detached and have gardens.

- The entrances are positioned at the center of the building.

The houses were built using mixed construction systems. The ground floor is built of stone masonry, while the upper floors are built from a karkas filled with brick or mudbrick.

_ The houses have two or three floors. The taşlık, warehouse, cellar and woodshed are on the ground floor, while the upper floors consist of lived-in units, such as rooms, kitchens and bathrooms.

- The plans consist of interior halls, with the rooms arranged around the sofa. In some examples, a section of the sofa ends with a cantilever and a seating unit. When home to large families, this section can be closed off and turned into a small room.

The houses usually have a cantilevered bay window. The overhangs are generally positioned in the center of the structures and are supported by wooden buttresses.

- The facades are covered with white plaster. Sometimes blue dye was also added.

_ The facades are generally plain. Some examples include light decorative elements. There are profiled wooden decorative elements on the corners of facades. Profiled wooden cornices used in a combination of the roof and the top floor are also a characteristic feature. Triangular pediments or curved wooden details on the windowsills are other examples of decoration.

- An effort is made to make the most of natural light, with windowless facades almost never used.

Windows can be either rectangular, arched or trellised. Rectangular windows are most common. Arched windows are used only for bay windows. Lattice windows provide privacy on the ground floors but are very seldom used in Boyabat's houses.

- The entrances are wooden, double or triple-partitioned, double-leaf doors. Windows are another feature.

The roofs are hipped and covered with Turkish-style tiles.

Other examples of traditional architecture with similar characteristics make up the district's historical heritage. Some of these historical buildings have been registered by the municipality. Like traditional Turkish houses, religious and traditional rules influenced their interior design. Minimalist and environmentalist approaches are common in Boyabat's houses.

Having buildings restored is important to reviving traditional houses but is not enough on its own. Restored buildings dotted the city, but work that improves streets as a whole, rather than individual houses, and protects the historical heritage of the streets, will revitalize the region. This will kickstart a cultural revival so that the houses that still preserve their authenticity will not be destroyed. Urban-scale studies can revive Boyabat's houses and is an important step toward preserving the region's traditional heritage.

Declaration of interest: The authors report no conflict of interest funding statement.

Funding: None.

\section{Acknowledgements}

This study was produced from a dissertation which was made by Zeyneb Ayla Kirenci Eruzun in Fatih Sultan Mehmet Vakıf University, Faculty of Architecture and Design in 2018. 
Başkan, S. "Geleneksel Doğu Karadeniz Evleri” [Traditional Eastern Black Sea Houses]. Erdem (2008): 41-90 <https://dergipark.org.tr/tr/pub/erdem/issue/43874/539857>

Başoğlu, B. Boyabat ve Çevresi Tarihi [History of Boyabat and its surroundings]. Ankara: Doğuş Matbaaclık (1972).

Beceren Öztürk, R., Çahantimur, A. and Acun Özgünler, S., Examining Authenticity of Traditional Turkish Houses in Bursa, A UNESCO Heritage Site, The Historic Environment: Policy and Practice, Vol. 8, 2017, No. 1, 3-24, https://doi.org/10.1080/17567505.2017.1295559

Bostancıoğlu, E. ve E.D. Birer, 2004, “Ekoloji ve Ahşap-Türkiye'de Ahşap Malzemenin Geleceği” [Ecology and wood - The future of wooden material in Turkey] Uludağ Üniversitesi Mühendislik Mimarlık Fakültesi Dergisi, cilt:9, sayı:2.

Çobancaoğlu, T. Türkiye»de Geleneksel Ahşap Ev Yapı Sistemlerinin İrdelenerek Gruplandırılmasına Yönelik Bir Değerlendirme, Tasarım+Kuram [An evaluation regarding the analysis and grouping of traditional wooden house structures in Turkey, design + theory]., 2 (3), (2003). https://doi.org/10.23835/tasarimkuram.240843

Eldem, S. H. Türk Evi Plan Tipleri [The plan typology of Turkish house], İstanbul Teknik Üniversitesi Mimarlık Fakültesi. İstanbul: Pulhan Matbaası, (1954).

Esemenli, D. Sinop Illi Türk Dönemi Mimarisi [Architecture of Turkish period in Sinop]. Doktora Tezi. İstanbul Üniversitesi Sosyal Bilimler Enstitüsü (1990).

Eser, E. Boyabat Kalesi [The castle of Boyabat]. C.Ü. Sosyal Bilimler Dergisi, 30 (2), (2006).

Hasol, D. Ansiklopedik Mimarlık Sözlüğü [Encyclopedic architectural dictionary] (Geliştirilmiş 11. Baskı). İstanbul: YEM Yayın, (2010)
Karaman, Ö. Y., Zeren, M. T., 2015, Case Study: Examples of Wooden Vernacular Architecture - Turkish Houses in Western Anatolia, YBL Journal of Built Environment, 77-87 https://doi.org/10.1515/jbe-2015-0008

Kuban, D. Türk Ahşap Konut Mimarisi 17.- 19. Yüzyıllar TTurkish wooden housing architecture, 17.-19. centuries]. İstanbul: Türkiye İş Bankası Kültür Yayınları (2017).

Kuban, D., Türk Hayatlı Evi [Turkish lively house], Sayfa: 59, Mısırlı Matbaacılık, İstanbul, (1995).

MEHMET ÖZ, “SINOP”, TDV İslâm Ansiklopedisi [Sinop, TDV Islamic Encyclopedia], https://islamansiklopedisi.org.tr/sinop (15.09.2020).

Özen, H., Keleş, S. and Engin, E., 2012, Vernacular Building Heritage in the Eastern Black Sea Region in Turkey, Journal of Civil Engineering and Architecture, Volume 6, No. 7, pp. 867-875. https://doi. org/10.17265/1934-7359/2012.07.009

Saatçi, S., Esmer, M. ve İsmailoğlu, H., 2018, Kastamonu İhsangazi İlçesi Köy Mimarisi [Rural Architecture in İhsangazi District of Kastamonu], S. 29, Kerkük Vakfı, İstanbul.

Seçkin, N., Erdem, A. ve Özakın R., Sinop-Boyabat Kentsel Mimarlık Envanter Raporu 2002 Yılı Çalışması [Sinop-Boyabat urban architecture inventory report 2002 study], TÜBA Kültür Envanteri Dergisi 90-105, (2002). https://doi.org/10.22520/tubaked.2003.0004

Tosun, H. T.C. Sinop Valiliği Il Kültür ve Turizm Müdürlüğü, Sinop Tarihi ve Kültür Envanteri [Sinop history and cultural inventory] (2013).

Zeyrek, A. Boyabat İlçe Analizi [Boyabat district analysis], Kuzey Anadolu Kalkınma Ajansı, Kastamonu, (2013).

\section{ZEYNEB AYLA KIRENCI ERUZUN}

\section{Research Assistant}

Department of Architecture, Faculty of Architecture and Design, Samsun University,

Samsun/Turkey

\section{Main research area}

Architectural design, architectural design education, traditional architecture

\section{Address}

Samsun University, Canik Campus, 55080

Canik/Samsun/ Turkey

E-mail: zeynebayla@gmail.com

\section{SUPHI SAATÇI}

Professor

Department of Architecture, Faculty of Architecture and Design, Fatih Sultan Mehmet Vakıf University, İstanbul/Turkey

\section{Main research area}

Vernacular architecture, cultural heritage, restoration

\author{
Address \\ Fatih Sultan Mehmet Vakıf University Haliç Campus, \\ 34445 Sütlüce/İstanbul/Turkey \\ E-mail: ssaatci@fsm.edu.tr
}

\section{About the Author}

